\title{
Importance of Non Timber Forest Production in Sustainable Forest Management and Its Implication on Carbon Storage and Biodiversity Conservation in Case of Ethiopia
}

\section{Solomon Melaku Melese*}

Department of Forestry, College of Agriculture, Wollo University, Dessie, Ethiopia

\begin{abstract}
Non-timber forest products (NTFPs) are biological resources of plant and animal origin, harvested from natural forests, manmade plantations, wooded land, farmlands, and trees outside forests and or domesticated. These products are vital sources of income, nutrition and sustenance for many forest-based communities around the world. This paper tries to review available and accessible literatures on role of NTFPs in sustainable forest management and its implication on carbon storage and Biodiversity conservation in case of Ethiopia. Including Sociological Approach, Economic Approach, Ecosystem Approach, Technological Approach and its related services (biodiversity conservation and carbon sequestration). The use of Non Timber Forest Products (NTFPs) has received attention in light of their Perceived potential to address both poverty reduction and tropical forest conservation. Moreover, management of NTFPs, factors that hamper sustainable managements of NTFPs. It was suggested that better management and utilization method has to be set for diversifying products benefit for the local community.
\end{abstract}

Keywords: NTFPs; Sustainable; Biodiversity

\section{Introduction}

Non timber forest products (NTFPs) are, in broadest sense, any biological resources collected from wild by rural people for direct consumption/income generation on a small scale [1]. They include such as wild edible foods; medicinal plants; floral greenery; horticultural stock; fiber of plants; fungi; resins; fuel wood; small diameter wood used for poles, carvings etc. [2]. Interests in NTFPs was predicated upon a few assumptions these include: commercial exploitation of NTFPs is less ecologically destructive than timber harvesting and thus has greater potential for sustainable forest management; local forest users exploit forest resources wisely and sustainably and NTFPs will more directly benefit people living near forest compared to timber harvesting [3].

There has been increasing recognition of NTFPs contribution to household and national economies and environmental objectives including biodiversity conservation [4]. For example, a study by MEA (2005) estimated that up to $96 \%$ of the values of forest are derived from NTFPs and services. Also, they have been recognized internationally as an important element in sustainable forestry. The UNCED in 1992 identified sustainable forest management as a key element in sustainable economic development and set out nonbinding guidelines for sustainable forest management with specific inclusion of NTFPs [5].

Similarly, Plotkin and Famolare (1992) [6] ascertained it by stating that there was a big concern on how to address the increasing and expanding deforestation of tropical forests. At that time ecologists tried to answer how to make forest resource economically attractive to local people to reduce deforestation. NTFPs were among options considered best strategies to raise income for local people from forest while addressing conservation objectives [7]. Since then, sustainability of NTFPs extraction has been topic of debate due to the underlying objective of development and conservation are basically linked. For instance, EARO and IPGRI (2004) [8] argued that contribution of NTFPs to livelihoods of rural communities is likely to persist as long as the resources are exploited on sustainable basis. This has led in a global move towards developing management of natural forest for the benefits of local communities [9].

Biodiversity is the variability among living organisms from all sources including terrestrial, marine and other aquatic ecosystems and the ecological complexes of which they are a part. This comprises diversity within species, between species and of ecosystems [1013]. Particularly NTFPs is one option for slowing the rise of GHGs concentrations in atmosphere is to increase amount of carbon remove and store in forests [14]. CS is defined as an increase in Carbon stocks other than in the atmosphere $[11,15]$.

\section{Basics of NTFPs, Sustainable forest Management and its Related Services}

\section{Non timber forest products (NTFPs)}

NTFPs have many definitions in the literature. Thus, it is hardly to encounter single definition of NTFPs in the existing literatures Gary and Kristin, 2005 [16]. This is due to the fact that different individuals and/or organizations have modified the definition in different ways to suit their needs $[17,18]$. Accordingly, definition of NTFPs for this paper is provided in the background section.

\section{Sustainable forest management (SFM)}

There is no standard definition of SFM. However, according to Chamberlain et al. (2002) [19], SFM is built on the principle that

*Corresponding author: Solomon MM, Department of Forestry, College of Agriculture, Wollo University, Dessie, Ethiopia, Tel: 0333115204; E-mail: solomon.melaku@wu.edu.et

Received March 23, 2016; Accepted May 24, 2016; Published May 31, 2016

Citation: Solomon MM (2016) Importance of Non Timber Forest Production in Sustainable Forest Management and Its Implication on Carbon Storage and Biodiversity Conservation in Case of Ethiopia. J Biodivers Endanger Species 4 160. doi: $10.4172 / 2332-2543.1000160$

Copyright: ( 2016 Solomon MM. This is an open-access article distributed unde the terms of the Creative Commons Attribution License, which permits unrestricted use, distribution, and reproduction in any medium, provided the original author and source are credited. 
forest management will meet current societal needs without affecting future generations, or the forests' abilities to rejuvenate. This concept holds three fundamental standards: forest management is socially acceptable and equitable; the impact is ecologically benign and the economic impact to local communities is positive. In similar fashion, it was stated that sustainable forest management is type of management that maintains and enhances long-term health forest ecosystems, while providing economic, social and cultural opportunities for the benefit of present and future generations [20].

\section{Non-timber forest products in Africa}

Although NTFPs play a major role in the rural economy of Africa, information on their overall contribution is patchy and incomplete at best, except for a few species and products of commercial importance (FAO, 2003) [21]. The lack of systematic efforts to conserve and manage resources is a major concern and it is in only a few cases that efforts have been made to cultivate species that yield NTFPs. African forests are a source of a variety of NTFPs such as fruits, gums and resins, honey and beeswax, medicinal and aromatic plants, dying and tanning materials, bamboo, and bush meat. These products are of critical importance to the livelihoods of rural communities and, in some situations, account for a significant share of household income (FAO, 2003) as a source of food.

Increased demand has not necessarily led to improved management including domestication, and a substantial proportion of products are collected from the wild, hence resource depletion is a major problem (FAO, 2003). Further, Africa has not been able to take advantage of its wealth of raw material and traditional knowledge and investing on processing undermining opportunities for employment and income generation. Concluded that the main effects of harvesting whole individuals would be via genetic drift and indirect selection. In contrast, harvesting only reproductive structures would most likely affect gene flow, the mating system and direct selection.

Throughout Africa, numerous medicinal plant species are becoming increasingly scarce due to a rise in trade to meet the demand from growing urban populations Marshall, 1998. For example, favored species such as Dalbergia melanoxylon have declined in Kenya and South Africa through harvesting to supply the woodcarving trade. Bark extraction has caused serious damage to wild populations of Prunus africana, including trees inside forests of high conservation value Cunningham et al., 2002. Warburgia ugandensis is another tree species threatened by exploitation of its roots, barks and shoots for medicinal purposes in East Africa. Boswellia papyrifera is one of the threatened species in Ethiopia due to over exploitation or improper tapping of its frankincense and lack of regeneration Abeje, 2002.

Unless harvesting is controlled, some species will therefore become genetically impoverished or depleted more rapidly than others Arnold and Perez, 2001 [4]. Exploitation of NTFPs from the wild in many respects and depending on the plant part harvested can help for sustainable utilization of the species. However, this requires understanding growth and reproductive characteristics of the plants and the application of harvesting practices that permit adequate reproduction or regeneration of the individual organism [22]. Domestication of the species in question is another alternative in cases where exploitation of NTFPs from the wild cannot be sustainable.

\section{Important NTFPs in Ethiopia}

Due to its varied ecological and climatic conditions, Ethiopia is home to some of the most Diverse flora and fauna in Africa. NTFPs in
Ethiopia cover a wide range of products and are most extensively used to supplement diet and house hold income, notably during particular seasons in the year, and to help meet medicinal needs. They are largely important for subsistence and economic buffer in hard times.

These products contribute to the improvement of the livelihoods of rural communities by providing food, medicine, additional income, and employment opportunities and foreign exchange earnings of the country. In addition, by complementing wood-based management, they offer a basis for managing forests in a more sustainable way, thereby supporting biodiversity conservation. Historically, early forestry work tended to ignore this fact; it was mainly focused on managing forests for the continued supply of timber. The significant value and importance of NTFPs is felt more in dry land areas where few alternatives of resources exist for supporting the livelihoods of local communities because of difficult environmental conditions (EARO, Unpublished).

In Ethiopia, non-farm income represents an important element in the livelihoods of the poor. In several areas, where the population density and depletion of natural resources are high, agriculture cannot possibly remain the only source of income. Observations show that, in many areas, crop production is no longer the main source of income for poor rural households RESAL, 2000. Therefore, it is essential for rural households to look for non-farm activities like productive exploitation of NTFPs to supplement agricultural production.

The most important NTFPs in Ethiopia include coffee; spices and condiments; honey and wax; bamboo; reeds; natural gums such as gum Arabic, frankincense and myrrh; edible plant products like leaves and shoots, fruits, seeds, tubers, mushrooms, edible oil, and fat; fodder; fibers; bark, simple sugar products; essential oils; tannins and dyes; resins; latex; ornamental plants and giant/long grasses (EARO, Unpublished).

Spices harvesting is practiced in many forest areas of southern Ethiopia, such as Sheka, Keffa, Bench Maji, South Omo and Gamo Gofa Zones [23]. Commercial spices such as Aframomum corrorima (Korerima) and Piper capense (Timiz) are found as indigenous species in Shekicho-Keficho and Bench Maji forests and woodlands.

Beekeeping is an ancient tradition in Ethiopia with annual production of about 24,000 tons of honey. This is a third of the total honey production in Africa. The density of hives is estimated to be the highest in Africa. An estimated 4-10 million traditional beehives and some 10000 modern boxes exist in the country vivero, 2001 [24]. The main products of the beekeeping industry are honey and wax. Honey is almost exclusively consumed locally, while a considerable proportion of wax is exported.

Ethiopia is one of the few tropical countries well-endowed with diverse plant species that yield economically valuable gum and aromatic resins such as gum acacia, frankincense and myrrh Wubalem et al., 2003; Mulugeta and Demel, 2003. The commercial use of natural gums is an age-old activity in Ethiopia. Ethiopia has been one of the major producers and exporters of natural gums from different indigenous tree species of the genus Acacia, Boswellia and Commiphora, which are found in different agro-ecological zones of the country [25].

Ethiopia has $67 \%$ of Africa's bamboo resources which is about $7 \%$ of the world total [26]. It has about 1 million ha [26,27] of highland bamboo. Arundinaria alpina accounts 150, 000 ha, out of which 130 000 ha is natural and 20,000 ha human made bamboo plantations owned by framers. Lowland bamboo is dominant with coverage of 
700,000-850,000 ha. Bamboo provides food, fodder, furniture and building materials (scaffoldings), industrial inputs, medicinal plants and fuel. Solid bamboo has been tested as a concrete reinforcement to substitute steel and the results have revealed success.

The overall socio-economic and ecological importance and contribution of NTFPs in Ethiopia is significant, diversified and valuable. The harvesting, commercialization and transformation of certain NTFPs by the rural poor can be a means of shifting efforts away from the unsustainable exploitation of ecologically sensitive forest products. The NTFPs are among the main coping mechanisms that poor households and the nation have. Thus, their importance should not be overlooked or underestimated.

The link between NTFPs and forest sustainability and its services: Forest biodiversity is being lost at an alarming rate. Publications of MEA (2005) [28] indicate that a large and increasing number of forest ecosystems, populations and species are threatened globally or being lost due to the loss and degradation of forest habitats.

The link between NTFPs and forest sustainability and its services (biodiversity conservation and carbon storage) can be understood by taking in to consideration of some cases. For example, In the BioCarbon fund project of CDM in Niger, Acacia senegal Plantation aimed to reforest Over 17,000 ha of degraded land, expected to sequester about 1.8 million t CO2 in the near future (2017). With strong local social and environmental benefits: income generation through carbon payments, gum production, rehabilitation of degraded land and biodiversity NTF-PSI, 2008 [29]. Likewise, in case of Ethiopia, Humbo Assisted Regeneration Project is aimed to restore 2,728 ha of biodiversity natural forest and expected to sequester about 750,000 t CO2 in 30 years with benefits of improved community capacity to participate in carbon finance reforestation and improve their livelihoods (NTFPSI, 2008). Moreover, Mulugeta and Habtemariam (2007) discussed that vegetation of Acacia, Boswellia and Commiphora (ABC) can be managed to provide many functions (economical and ecological services). This will enable Ethiopia to fulfill international conventions that Ethiopia has ratified. Some of the Potentials of the vegetation, $\mathrm{ABC}$, for biodiversity conservation and carbon sequestration, are presented as follows:

ABC for biodiversity conservation: There are two possible states of affairs in that Acacia, Boswellia and Commiphora species can be managed to contribute to biodiversity Mulugeta and Habtemariam, 2007. (a) Through gum and incense extraction, as NTFPs. Extraction of gum and incense, when appropriately conducted, is non-destructive, and hence causes negligible damage to the biodiversity, this is in line with one of the few assumptions of NTFPs. For that reason, via proper gum and incense extraction for economic benefit, we can conserve the vegetation for their biodiversity value. (b) Through integration of the species into other economic sectors. Acacia, Commiphora and Boswellia species can be integrated with farming systems in different forms of agro forestry. Agro forestry, as one of integrated approaches to biodiversity conservation, is nowadays receiving considerable attention; since many species of Acacia, Boswellia and Commiphora have the necessary qualities to be integrated in agroforestry systems Mulugeta and Habtemariam, 2007.

$\mathrm{ABC}$ for carbon sequestration: Forests involve largest carbon pool of all terrestrial ecosystems $[30,31]$. This was supported by the study of Von (2006) [32] who stated that tree-based systems and carbon sequestered through process of photosynthesis remains fixed in wood and other organic matter in forests for long period of time.
In Ethiopia, land use changes such as deforestation and conversion of forests into farmlands are the principal sources of carbon dioxide emission Mulugeta and Habtemariam, 2007. As a Signatory of the Convention on Climate Change, Ethiopia has to work together in the ongoing Efforts for carbon sequestration by making use of various sink potentials. In dry lands of Ethiopia, the most viable approach to achieve significant carbon sequestration is by means of Productive vegetation management practices. The fact that Acacia, Boswellia and Commiphora can grow under harsh environment, means that there is even a potential to sequester carbon in extreme environmental circumstances. These plants can also act as wind breaks and, thus, reduce loss of soil carbon by wind; and intercept rain drops by their widely spreading canopies, reduce speed of surface run off and thus reduce soil erosion effectively thereby stabilizing soils and protecting soil carbon Mulugeta and Habtemariam, 2007.

As per the above Table 1, it is clear that the existence and coverage of the vegetation is almost throughout the nation. This indicates that there is a possibility to develop strategy for these vegetations, to provide socio-economic and environmental goods and service, at regional and/ or national level based on proper management of the vegetation.

NTFPs and community development: NTFPs were regarded as providing a very good opportunity for sustainable forest management and community development in the last two decades. There has been increasing recognition of their contribution to household economies and food security, to some national economies and particularly to environmental objectives, including the conservation of biological diversity [4].

The role of NTFPs to the livelihoods of rural communities is likely to continue as long as the resources are exploited on a sustainable basis. This in itself is not likely to result in tremendous community development since these rural communities have been using these resources for centuries. On the other hand, exploitation of NTFPs for commercial purposes contributes to local economies hence contributing to community development. The only drawback to this scenario is that commercialization also results in overexploitation and depletion of the resources. Therefore, a balance has to be stricken between resource sustainability and benefits of exploitation of products, particularly for the export market.

\section{Importance of NTFP for rural livelihood and poverty reduction}

NTFPs are components of the forest system that exist in nature and are generally not cultivated. Non-timber forest products (NTFPs) are plants or plant parts that have a perceived economic or consumption

\begin{tabular}{|c|c|c|}
\hline Region & Genus of the Vegetation & Estimated Area(ha) \\
\hline Afar & Commiphora \& Acacia & 65,000 \\
\hline Amhara & Boswellia, Commiphora,Acacia \& Sterculia & 680,000 \\
\hline Benshangul & Boswellia, Acacia \& Sterculia & 100,000 \\
\hline Gambles & Commiphora, Acacia \& Sterculia & 420,000 \\
\hline Oromia & Boswellia, Commiphora,Acacia \& Sterculia & 430,000 \\
\hline SNNP & Boswellia, Sterculia \& Acacia & 70,000 \\
\hline Somalia & Boswellia, Sterculia, Commiphora \& Acacia & $150,000-1,500,000$ \\
\hline Tigray & Boswellia, Sterculia, Commiphora \& Acacia & 940,000 \\
\hline Total & & $\mathbf{2 , 8 5 5 , 0 0 0 - 4 , 3 5 5 , 0 0}$ \\
\hline
\end{tabular}

Source: (Fitwi 2000; Lemenih et al., 2003 cited in Mulugeta and Habtemariam 2007).

Table 1: Estimated area coverage of vegetations with gum and resin bearing species in Ethiopia by region. 
value sufficient to encourage their collection and removal from the forest. It can also be referred to as all the resources or products that may be extracted from forest ecosystem and are utilized within the household or are marketed or have social, cultural or religious significance FAO, 1990. These include plants and plant materials used for food, fuel, storage and fodder, medicine, cottage and wrapping materials, biochemical, as well as animals, bird's feather, reptiles and fishes. NTFPs which are harvested from within and on the edges of natural and disturbed forest, may be all or part of a living or dead plant, lichens, fungi, or other forest organisms. It therefore, represents a diversity of potential products sought after by a wide variety of people on a continuum of scales and intensities (FAO, 1990). Apart from timber and firewood that are conceived as major forest produces, nontimber forest products (NTFP) include all products obtainable from forest. NTFPs indeed play a very significant role in the rural economy in terms of providing employment, income potential and life support sustenance Negi et al., 2011.

The past decade has witnessed a rapid growth of interest in nontimber forest products (NTFPs) among conservation and development organisations $[3,33]$. There are a number of reasons for the general spread and upsurge in global interest in NTFPs. It is believed that the promotion of sustainable use of NTFPs could lead to a win-win situation for poverty reduction and biodiversity conservation FAO, 1995; Shiva and Verma, 2002; Golam et al., 2008.

Utilization of NTFPs to create win-win options for forest conservation and improvement of local livelihoods depends upon how they are managed and governed in respect to both access to resources and access to the markets Laird et al., 2010. Effective governance of NTFPs is important throughout the management, harvesting, trade and use phases of most NTFPs. However, the governance of NTFPs was overlooked and poorly regulated in past years Laird et al., 2010.

This is due to the increasing recognition that NTFPs can contribute significantly to the livelihoods of forest dependent communities Clendon, 2001; Belcher et al., 2005; Marshall et al., 2005; Ros-Tonen and Wiersum, 2005; FAO, 2006; Ahenkan and Boon, 2010; household food security and nutrition FAO, 1995; Falconer, 1997; Clark and Sunderland, 2004; Shacleton and Shackleton, 2004; Ahenkan and Boon, 2008[22,1]; generate additional employment and income Peters, 1996; Ros-tonen, 1999; Andel, 2000; Marshall et al., 2003 and offer opportunities for NTFP based enterprises [1]. Moreover, NTFPs are more accessible to the poor Saxena, 2003; contribute to foreign exchange earnings Andel, 2000 and support biodiversity and other conservation objectives FAO, 1995; Arnold and Ruiz Pérez, 1998; Marshall et al., 2005; Charlie and Sheona, 2004.

The concept of NTFPs, therefore, became an economically acceptable ecological option of development. There was also an assumption, often implicit Belcher 2003 [17], that making forests more valuable to local users can encourage forest conservation and poverty reduction Ahenkan and Boon, 2008; Mbuvi and Boon, 2008. NTFP-based development was, therefore, born as a new development paradigm Choudhury, 2007 capable of accommodating many conflicting needs of forest depending communities. Within the context of emerging new international commitments to address rural poverty, such as the Millennium Development Goals (MDGs), the commercialization of NTFPs is recognized as having the potential to achieve dual conservation and development goals by increasing the value of forest resources to local communities for poverty reduction and human development FAO, 1995 Neumann and Hirsch, 2000; Marshall et al. 2003; Wunder and Angelsen, 2003 [33]. Globally, inter- national trade in NTFPs is estimated at USD 11billion annually Ndoye and Ruiz Pérez, 1998; Shiva and Verma, 2002; Marshall et al., 2005; Ahenkan and Boon, 2010.

Non Timber Forest Products (NTFPs) are harvested for both subsistence and commercial use, either regularly or as a fall-back during times of need. They add to peoples'livelihood security, especially for rural dwellers. NTFPs may also have marked cultural significance and value [1]. NTFPs are conventionally viewed as the products of the poor unlike that of the timber for the rich.

However, evidence indicated that in developing countries forest products are also an integral component of the livelihood of a sizeable proportion of urban households [7]. In several studies on the role of NTFPs in rural livelihoods, various strategies for incorporating these products in the livelihoods systems have been identified. Usually, much attention is given to relate the different livelihood practices to the economic characteristics of a species Belcher et al., 2005 and to the access to markets Belcher and Schreckenberg, 2007; Ros-Tonen and Kusters, 2011.

NTFPs cover a wide range of products with different characteristics, which are utilized in a variety of context and play important roles in various household livelihood strategies. This involves thousands of plant and tree species, most of which are consumed within the household of the gatherers and are not traded in markets. Studies conducted by Shackleton and Shackleton, 2004 [1] show that extraction, processing, and trading of NTFPs is often the only employment available for the population in remote rural areas. Adepoju (2007) indicate that NTFPs are a dependable source of income and food supply in the rural areas. However, it is a diminishing resource as a result of its dependency on land which is known to be under pressure of depletion from agriculture and development of public infrastructures. Several opportunities for improved rural development are linked to NTFPs. In many areas, rural populations are traditionally depending on local forest resources to provide additional income through collection and marketing of NTFPs.

Where employment opportunities from traditional industries are declining, workers looking for alternative income sources often turn to collection of these products from nearby forest. NTFPs also play a role in the household economy of not only the poor, but also the rich Nguyen, 2006. In Vietnam, more than 320,000 people are involved in NTFP production Riadh, 2007. There is a growing agreement that NonTimber Tree and Forest Products (NTFPs) play an important role in the livelihoods of the rural poor as a source of food, medicine, construction materials, and income. It has been estimated that there are more than 60 million highly forest dependent people in Latin America, West Africa, and Southeast Asia, with an additional 400-500 million people directly dependent on these natural products Riadh, 2007. Subsistence use of NTFP represents the greater part of its value to households. However, they are also source of cash income such income seldom appears to account for a large share of a households total income, but complements other livelihood activities [1]. Being able to collect and use NTFP to a meet daily needs of energy, shelter, food and medicine, allows the scarce cash resources to be used to secure other household needs and to attempt to accumulate the necessary asset base for a more secure livelihood. This includes the education of children, investment in agricultural tools, or capital for activities that generate income. Such a cost saving would best be reflected by replacement values of the goods that the NTFPs substitute, rather than direct-use value based on farmgate prices [1].

As discussed above, some NTFPs serve as safety net or as poverty 
trap while others may provide regular, important cash income and household self-sufficiency, food security, income generation, accumulation of savings and risk minimization. They also provide input for agriculture, small scale enterprise and bases for capital formation. According to Shackleton and Shackleton (2004) NTFPs provide livelihood benefits in assisting households to cope in times of adversity manifested as sudden changes in the economic, social or bio-physical environments in which households exist and function. It provides the poor quick cash or auto consumption goods especially in the event of unpredicted shortfalls, such as failure of agricultural crop or disasters Angelsen and wunder, 2003. Shackleton and Shackleton (2004) stated that this sudden change includes events like a death or retrenchment of the head of the household, droughts, floods, frosts or disease leading to crop failure or death of livestock, major economic structural adjustment, or unanticipated and large increases in costs of staple foods and goods. During such times it is common for rural households to turn to NTFPs to tide them over what they perceive is a temporary setback. In these situations the changed types or species of NTFPs not often used by that household, increase consumption of products already part of their livelihood and temporary sale of NTFPs on local and regional markets, including within communities and between neighboring households use of NTFPs is typically a coping strategy, with the products providing a safety or emergency net to peoples livelihood.

Money earned from the sale of forest products has been shown to complement agricultural income and provide financial cost of health, and house hold expenses [4]. So safety net function of NTFP provides rural poor against falling into poverty by reducing their vulnerability to such risk. Studies by Ruiz Perez and Arnold (1995) indicated that NTFP-based activities can be important in filling seasonal and other food or income gaps can provide a buffer in times of hardship or emergency, is an activity of last resort, or can present an opportunity for improving household income and security. The risk-management role of forest products is particularly important in the rural regions of developing countries, given that agricultural crops face many types of risk, such as price shocks, seasonal flooding, unpredictable soil quality, pests, crop diseases or illnesses. NTFP can be used directly in consumption or sold to fill cash gaps World Bank, 2001. Moreover low capital and skills requirements of NTFP extraction as well as open or semi-open access to the resource, provides poor households to easily extract the resource Delacote, 2008. Godoy et al., (1997) had also noted in a study in Honduras, that although NTFP extraction has a low annual value, it can provide insurance in the case of unexpected losses. The coping strategy (observed in Africa) consists of extracting NTFP only in the case of bad agricultural crops. The use of NTFP can here be considered as an ex post gap filling use. Forest products are extracted in order to smooth the household's consumption in case of low crop returns [1]. Access to forest resources helps rural households diversify their livelihood base and reduce their exposure to risk. Earnings from forest products are often important as a complement to other income. Very large numbers of households generate some of their income from selling forest products, often when farm production is not enough to provide self-sufficiency year round. Income from forest products is often used to purchase seeds, hire labor for cultivation, or generate working capital for trading activities Warner et al., 2008. Safety net allows money to be saved and spent on other livelihood strategies such as agriculture which may in turn contribute to the household's sustainability. So safety net function of NTFP had a benefit for those who use the resources frequently in large quantity and occasionally.

\section{Management of Non Timber Forest Products}

\section{Theoretical concepts in NTFPs management}

The process, by which resources are allocated, regenerated, managed and conserved over time and space to meet the needs of humankind has been termed as resource management [34]. on the same document, resource management involves an interaction of three major elements. These are: physical resource base (land, water, forests, wildlife, etc.), Production system (the mix of technologies and productive activities) and social regulation (laws, rules and principles).

NTFPs management encompasses ecological, technical, social, economic, legal and political Aspects [34] as an ecological concept it deals with complex ecosystems that need to be monitored and maintained. Its technical aspect involves choice between different methods, techniques and development of appropriate harvesting and processing technologies. The social aspect of resource management also deals with people, cultures, belief systems, attitudes and behavior, ethics, aspirations and social values, and its economic aspect aims at maximizing benefits and efficiency from a resource and minimizing input costs.

In case of NTFPs, the social aspect also entails dealing with competing and voracious demands of people invariably place on the shrinking resources. Finally, resource management is a political subject because it involves exercise of power and control over users of resources and this raises issues of administration and decision making Karki, 2001

\section{Management approaches of NTFPs}

Non timber forest products management is a process involving harvesting, gathering, utilization and management of resources within a given ecological, economic, social, political, institutional and legal frameworks Karki, 2001. Further, it was discussed that in past times, focus on forest resource management has been in sector and single purpose user centered, that was solely giving the responsibility of resource management to technical expert such as forester and biological scientists. This scientific approach has neglected, traditional resource management based on local people's knowledge, cultural values and needs.

Moreover, the multidisciplinary and integrated nature of resource management in which intersectional and synergistic linkages has often been ignored Karki, 2001. With the increasing recognition of the limitations of such centralized approaches in recent years, a need has been felt for more holistic and integrated approaches for sustainable management of NTFPs resources.

Sociological approach: This approach emphasizes on significance of culture, ecological and social ethics, indigenous knowledge, the role of local people and social institutional arrangements in resource management. The sociological aspect of resource management has been the most neglected area in the resource management strategies of many countries until recently Karki, 2001. For instance, Chambers (1991) [35] examined that failure of a number of resource management programs was associated to the disregard of local culture and wisdom. This approach involves research methods such as PRA and institutional arrangements including administrative structures and procedures, policies and laws and financial management Karki, 2001.

Economic approach: This approach is based on the principle that there is a need to rationalize the allocation of natural resources and optimize their use through competitive market economies to achieve 
maximum economic efficiency Karki, 2001. However, this approach is limited as it assumes that firstly, cost and benefits from the use of natural resources must be known and quantifiable and secondly costs and benefits from one resource need to be isolated from those of another. But sometimes it is difficult to price/determine economic value of intangible benefits from natural resources such as ecological uniqueness, biodiversity, etc. Moreover, minimizing production costs and maximizing monetary benefits in order to strive for economic efficiency tends to increase pressure on some resources and neglect other resources for being of little/no significance in terms of economic development.

Ecosystem approach: This approach considers the whole ecological system and the relationship among its various components [34,36]. It recognizes the dynamics of the ecosystem as the basis for resource management. The approach aims at the rational allocation and management of resources based on ecological characteristics, component behavior, change processes and functional relationships among different components within ecosystems Karki, 2001. The primary concern is to manage resources in a manner that minimizes ecological destruction.

This approach involves practices such as; resource inventory, identification of natural processes that affect ecological stability; evaluation of functional significance of different components in an ecosystem and design of alternative management strategies to ensure ecological stability, productivity and sustainable development. Ecosystem approach is based on three perspectives represented as follows:

Technological approach: This approach comprises comprehensive land use or resource management plans and their implementation for rational allocation and utilization of natural resources based on the land capability classification. It is aimed at monitoring and mitigating environmental change using physical tools and modern technologies like mapping, geographic information system (GIS), remote sensing(RS) etc., environmental impact techniques, biotechnology and other techniques Karki, 2001. Ecosystem approach is based on three perspectives represented on Figure 1.

\section{The contribution of NTFPs extraction to forest conservation}

Some NTFPs inter into international market, even though most

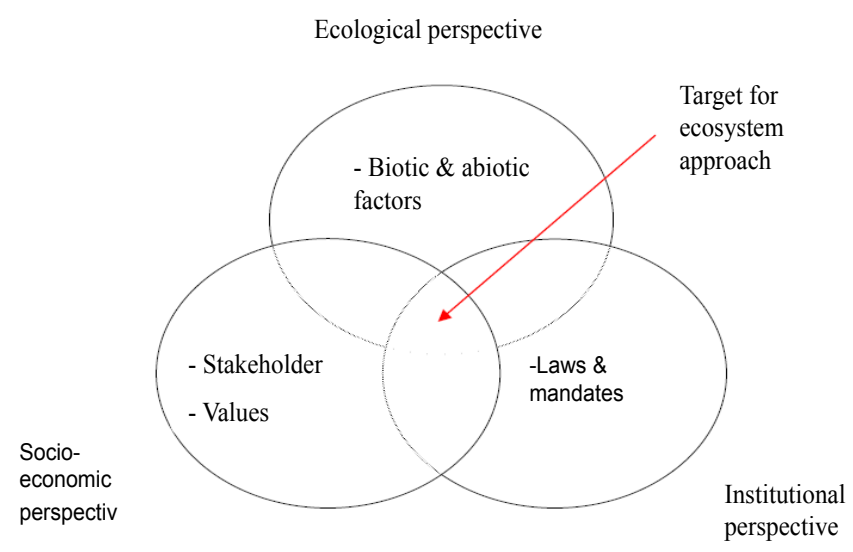

Source: Adapted from Pawlos (2010)

Figure 1: Ecosystem approach on different perspectives. of them locally used as food, medicine etc. [37]. Among the NTFPs that inter the international markets are: honey, palm heart, plant and animal input to the pharmaceutical industry, bamboo, essential oils and gum Arabic. In relation to this commercial extraction of NTFPs through adding value to the forest product it may provide an incentive to conservation and sustainable forest management. Similarly, Andel (2006) [38] stated that commercial NTFP extraction may contribute to forest conservation because collectors often protect useful trees from being logged.

Moreover, if people can earn a living by selling NTFPs, they will not need to involve in other environmentally more destructive activities. Increased income from trade of NTFPs is thought to provide stimulus for local communities to protect their forest and manage sustainably Ros- Tonen, 2000 [37]. Many NTFPs can be harvested without significantly changing the forest, hence maintaining the forest environmental services and biological diversity Ros-Tonen, 2000. On the other hand, any harvesting of NTFPs have ecological impacts including, gradual reduction of vigor of harvested plant species, decreasing rate of seedling establishment peters, 1996 cited in RosTonen, 2000. However, comparing to that of logging and conversion of land to other land use these ecological impact were viewed as minimal. Ros-Tonen (2000) stated that it is incorrect to suggest that NTFPs are harvested indefinitely without proper management practice to sustain their yield.

\section{Factors that Hamper Sustainable Management of NTFPs}

\section{Ecological factors}

Ecological issues, if not addressed, could result in long-term and perhaps permanent decline in biological diversity [19]. The same document revealed that current scientific knowledge cannot adequately determine sustainable harvest levels of biological resource from which NTFPs collected; research is needed to examine and determine effects of harvesting on plant populations, as well as the impact on associated forest ecosystems, and concluded that sustainable forest management will remain exclusive until knowledge concerning NTFPs is developed. Neumann and Hirsch, (2000) [33] supported this idea by stating efforts to measure the direct ecological impacts in actual NTFPs harvesting systems, is not easy since most real world situations are complex that other underlying factors are hard to filter out.

Nevertheless, many studies have tried to deal with it. For example, seventy studies have quantified ecological effects of harvesting NTFPs from plant species perspective, with aims of assessing current state of knowledge and illustrated that NTFPs harvest can affect ecological processes at many levels, from individual to ecosystem [39]. In this case, it was evidenced that intensive annual harvesting of a valuable market fruit or oil seed can gradually eliminate a species from a forest ecosystem [3]. Ecological impacts of NTFPs harvest is not only observed in plants but also in animals. For instance, Fitzgibbon, et al. (1995) [40] stated that bush meat harvesting has the potential to alter ecosystem structure and functioning where one/more important animal species are depleted.

\section{Change in socio-economic and institutional aspects}

It is clear that transport systems are reaching further into remote areas, catalyzing forest and woodland clearing for different purposes and this result in the loss of supplies of wild harvested species as habitat declines. For this reasons, Wilkie et al. (2000) cited in SCBD (2001) [41] underlined the need, through co-ordinated land-use and infrastructure planning, to plan roads in a way that maximizes local and 
national economic benefits while minimizing the negative effects road construction has on biodiversity. Since the 1960's, growing demand from urban areas has catalyzed NTFPs trade, drawing resources from rural areas to towns and cities, for fuel wood, building materials, medicinal or edible wild fruit species (SCBD, 2001). Consequently, urbanization has tended to increase rather than reduce the demand for wild plant resources that stimulates overexploitation.

According to Chamberlain et al. (2002) [19] three major institutional weaknesses were important to have impact on sustainable forest management efforts. First, staff levels and expertise were inadequate to deal with non-timber forest products. Second, institutional impediment to sustainable management of NTFPs was that the biological materials from which these products originate are not recognized nor treated as other natural resources(such as timber, and minerals) and third, lack of funding to support sustainable forest management activities.

\section{Some Suggested Points Concerning Sustainable Managements of NTFPs}

Ticktin, (2004) [39] suggested that, so as to manage and conserve NTFPs populations effectively, at least three ecological questions must be addressed in addition to socio-economic issues; these were: what are the ecological impacts of NTFPs harvest? What are the mechanisms underlying these impacts? And what kinds of management practices mitigate negative impacts and promote positive impacts?

It was also recommended that, feasible strategies and continuous action plan should be developed for conservation and sustainable utilization of respective source of NTFPs species and their habitat EARO and IPGRI, 2004 [8]. Similarly, Arnold and Perez, (2001) [4] recommended that approaches to conserve plant species that are source of NTFPs, need to be adapted to individual species and their habitat. Suggestion provided by SCBD (2001) [41] also support the same idea, that if policy on sustainable management of NTFPs is to be implemented successfully, then Policies and their implementation practice have to be tailored to local ecological, economic and sociopolitical circumstances.

Source of NTFPs populations managed by knowledgeable harvesters may show high growth rates under high harvest pressure, whereas populations of the same species managed by less knowledgeable harvesters may decline under much lower levels of harvest Ticktin and Johns 2002. It seems for this reason, EARO and IPGRI, (2004) [8] recommended that, public awareness needs to be created about the contribution of NTFPs at local and national level to promote sustainable utilization of products for economic and environmental benefits. On the other hand, Chamberlain et al. (2002) [19] suggested a helpful thought that, many collectors can trace their heritage and relationship with NTFPs back several generations and this traditional ecological knowledge is critical in understanding the fundamentals of NTFPs management.

Thus, Sustainable management strategies will require understanding and respecting peoples' views and uses of the NTFPs resource. Biodiversity of tropical forests with its millions of species, which have not yet been scientifically described, might hold many NTFPs for future uses in different sectors, thus conserving this biodiversity is critical. Good forest governance and incorporation of NTFPs in relevant national strategies and action plans are important steps for conservation and sustainable use of NTFPs resources SCBD, 2009 [42]. Furthermore, it was suggested that, it is indispensable to continue research on possibilities for NTFPs to contribute to sustainable forest management since NTFPs play important role in local forest use RosTonen 2000 [37].

\section{Summary}

NTFPs have been increasingly recognized for their contribution to economic development and sustainable forestry management. The link between NTFPs and forest sustainability could be understood by taking some cases into consideration (e.g. properly managed vegetation for gum and resin can store carbon and conserve biodiversity). This can led to sustainable forest resource management; since extraction of NTFPs can be conducted without significantly changing forest stands. However, Sustainability in NTFPs resources management is questionable without giving considerable attention to ecological, social, and economic aspects. On the other hand, there are some obstacles that restrain sustainable management of NTFPs related to ecological change, socio-economic change and institutional factors [43].

Eventually, some suggestions regarding sustainable management of NTFPs were provided. These were linked to impact of NTFPs extraction on species and ecology; management approaches; knowledge of collectors, integration of NTFPs in national strategies and need of Continuous research on NTFPs for forest sustainably [44].

Thus, based on the review, management approaches and practices of NTFPs in sustainable forest managements need to be adapted to local ecological, economical and sociopolitical circumstances. Responsibility of NTFPs management for forest sustainability should not be given only to an expert (forester) but also inclusion of traditional knowledge through involvement of stakeholders in management of forest resource is vital. Finally, further research on possibilities of NTFPs management for forest sustainability and its related services is needed [45].

\section{References}

1. Shackleton, Shackleton S (2004) The importance of non-timber forest products in rural livelihood security and as safety nets: a review of evidence from South Africa. South African Journal of Science 100: 658-664.

2. McLain RJ, Jones ET (2005) Non timber Forest Products Management on National Forests in the United States. General Technical Report PNWGTR-655. Portland.

3. Ruiz Perez M, Arnold JEM (1997) Current Issues in Non-Timber Forest Products Research (eds.). Proceedings of the Workshop 'research on NTFPs' Hot Springs, Zimbabwe.

4. Arnold MJE, Perez MR (2001) Can non timber forest products much tropica forest conservation and development objectives? Ecological economics, 39 437-447.

5. Jones ET, McLain RJ, Lynch KA (2004) The Relationship between Non timber Forest Product Management and Biodiversity in the United States. Institute for Culture and Ecology.

6. Plotkin M, Famolare L (1992) Sustainable Harvest and Marketing of Rain Forest Products. Washington, Island Press.

7. Ruiz-Perez M, Byron NA (1999) Methodology to Analyze Divergent Case Studies of Non Timber Forest Products and their Development Potential. Forest Science, 45.

8. EARO and IPGRI (2004) Conservation of genetic resource of NTFPs in Ethiopia in: proceeding of the first national work shop on NTFPs in Ethiopia, 5-6 April 2004 AA, Ethiopia, Wubalem Tadesse and Mbogga M (eds).

9. Hobley M (1996) Participatory forestry: the process of change in India and Nepal. Rural Development For Study Guide No.2:

10. Gillespie A (1997) Sinks, Biodiversity \& Forests: The Implications of the Kyoto Protocol For the Other Primary UNCED Instruments: Waikato University, New Zealand.

11. Huston MA, Marland G (2002) Carbon management and Biodiversity. Journa of Environmental management 00 (2003)1-10: Elsevier science Ltd., USA 
Citation: Solomon MM (2016) Importance of Non Timber Forest Production in Sustainable Forest Management and Its Implication on Carbon Storage and Biodiversity Conservation in Case of Ethiopia. J Biodivers Endanger Species 4: 160. doi:10.4172/2332-2543.1000160

12. Koziell I (2001) Diversity not Adversity: Sustaining Livelihoods with Biodiversity. Biodiversity and Livelihoods Group, IIED. Department for International Development.

13. United Nations Environmental Protection-UNEP (2007) Biodiversity and climate change. Convention on Biological Diversity: International day for Biological Diversity.

14. Gorte RW (2009) Carbon Sequestration in Forests. Congressional Research Service, USA.

15. Namayanga LN (2002) Estimating Terrestrial Carbon Sequestered In Aboveground Woody Biomass from Remotely Sensed Data. Serowe, Botswana.

16. Gary L, Kristin K (2005) Creating an Indicator for Non-Timber Forest Products.

17. Belcher BM (2003) what isn't an NTFP? International Forestry Review, 5: 161 168.

18. Rajesh R (2006) Analytical Review of the Definitions of Non Timber Forest Product. Institute of Forestry Pokhar.

19. Chamberlain JLH, AL, Araman PA (2002) Non-Timber Forest Products in Sustainable Forest Management. Forests of Southern United States.

20. Zewdie M (2009) Dry land forest management course. Dry Land Forestry Msc. Program, Hawassa University, Wondo Genet College of Forestry and Natural Resources.

21. FAO Food and Agriculture Organization for the United Nations (2003) Forestry outlook study for Africa: Regional report-Opportunities and challenges towards 2020. FAO Forestry Paper 141. FAO, Rome.

22. Sunderland TCH, Harrison ST, NdoyeO (2004) Commericialization of nontimber forest products in Africa: history, context \& prospects. Bongor, Indonesia.

23. Jansen PCM (1981) Spices, condiments and medicinal plants in Ethiopia: Their taxonomy and agricultural significance. Agricultural Research Report no 906. Wageningen Agricultural University, Wageningen.

24. Vivero JLP (2001) The role of forest resources in non-farm activities and their importance for rural livelihood diversification in Ethiopia: "Imperative problems associated with forestry in Ethiopia". Paper presented at the $\mathrm{XI}^{\text {th }}$ Annual Conference of the Biological Society of Ethiopia. Addis Ababa University, February 1-3, 2001.

25. Vollesen K (1989) Burseraceae In: I. Hedberg and S. Edwards (eds.), Flora of Ethiopia, Volume 3. Pittosporaceae to Araliaceae. National Herbarium, Addis Ababa University, Addis Ababa and Uppsala University, Uppsala. Unpublished 33.

26. Luso Consult (1997) Study on sustainable bamboo management. Technical Cooperation Ethiopia-Germany. Final report Hamburg, Germany.

27. Kassahun Embaye (2002) The indigenous bamboos of Ethiopia: A call for attention and action. Walia 20: 3-8.

28. Millennium Ecosystem Assessment-MEA (2005) Ecosystems and Human WellBeing: Policy Responses Vol.3, Island Press, Washington, DC.

29. NTF-PSI (2008) Targeted capacity building for avoided deforestation, reforestation and sustainable land management in Africa. November 13, 2008 Washington DC.

30. Gibbs HK, Brown S, Niles JO, Foley JA (2007) Monitoring and estimating tropical forest carbon stocks: making REDD a reality. Environmental Research Letter USA 2: 1-13.

31. Jandl R, Vesterdal L, Olsson M, Bens O, Badeck F, et al. (2007) Carbon sequestration and forest management. Perspectives in Agriculture, Veterinary Science, Nutrition and Natural Resources, Germany 2: 1-16.

32. Von V (2006) Incentive Mechanisms for a Sustainable Use System of the Montane Rain Forest in Ethiopia. Inaugural-dissertation, Berlin.

33. Neumann RP, Hirsch E (2000) Commercialization of Non Timber Fores Products: Review and Analysis of Research. Center for International Forestry Research, Bogor, Indonesia.

34. Karki M (2001) Institutional \& Socioeconomic Factors and Enabling Policies for Non Timber Forest Products Based Development in Northeast India. Paper presented in the Pre-identification Workshop for NTFP-led Development in NE India, Report No.1145.

35. Chambers A (1991) The Paradox of the Commons. Paper presented at the IASCP Annual Meeting, University of Manitoba, Winnipeg, Manitoba, and Canada.

36. Pawlos D (2010) Presentation on: Ecosystem Approach to Conservation Wildlife Management \& Echo-tourism, presented, Sept 25, 2010.

37. Ros-Tonen, MAF (2000) The role of non-timber forest products in sustainable tropical forest management.Holz als Roh.und Werkstoff 58: 196-201.

38. Andel T (2006) Non-timber forest products: the value of wild plants, Netherlands Wageningen.

39. Ticktin T (2004) Review: The ecological implications of harvesting non-timber forest products. Journal of Applied Ecology, 41: 11-21.

40. Fitzgibbon CD, Mogaka H, Fanshawe JH (1995) Subsistence hunting in Arabuko Sokoke Forest, Kenya, and its effects on mammal populations.

41. Secretariat of the Convention on Biological Diversity-SCBD (2001) Sustainable management of non-timber forest resources. Montreal technical Series no. 6.

42. Secretariat of the Convention on Biological Diversity-SCBD (2009) Sustainable Forest Management, Biodiversity and Livelihoods: A Good Practice Guide, Montreal.

43. Lemenih M, Kassa H (2007) Opportunities and Challenges for Sustainable Production and Marketing of Gums and Resins in Ethiopia. Proceedings of a National Workshop Held on December 5, 2007 in Addis Ababa, Ethiopia.

44. Putz FE (1994) Approaches to Sustainable Forest Management. Working paper, No.4 Sept 1994

45. Tadesse W, Teketay D, Lemenih M, Fitwi G (2003) Country report of Ethiopia In: Chikamai B. (Eds.). Review and synthesis on the state of knowledge of Boswellia species and commercialization of Frankincense in the drylands of East Africa. Association of Forestry Research Institutes in Eastern Africa 11-35. 